\title{
米国の株価指数連動年金に対する 証券規制を巡る論議の動向
}

小松原

章

\section{ロアブストラクト}

成長顕著な株価指数連動型年金に対して証券規制導入提案を行った SEC に対して，当該年金主力の生保業界が強い反対姿勢を示し，規則撤回を求め て連邦控訴裁判所に提訴した。裁判所は，規則の内容は妥当であるが，規則 導入に必要な効率性等の分析が不十分であるとして SECに対して再検討を 指示した。SEC は規則再提出意欲を示したが，おりからの金融危機後にお ける金融規制改革法案審議の過程で SEC 規制を排除する条項が組み込まれ た同法案が成立することとなった。これにより，証券規制は阻止できたが， 州の監督責任は一段と重くなり，その真価が問われている。

\section{ロキーワード}

年金，保険規制，連邦規制

\section{1. 米国個人年金市場と株価指数連動型年金の位置づけ}

世界最大の生保市場である米国の規模を ACLI（米国生保協会）の2010年 実績で見ると，収入保険料合計額（個人・団体計）で5,704億ドルとなって いる。これらの内の主な商品種類を見ると, 個人生命保険795億ドル，団体 生命保険 242 億ドル，個人年金 1,899 億ドル，団体年金 1,037 億ドル，個人医 療保険 812 億ドル，団体医療保険 905 億ドルとなっており，個人年金は最大の

$\overline{\text { / 平成 } 23 \text { 年 } 7 \text { 月 } 21 \text { 日原稿受領。 }}$ 
米国の株価指数連動年金に対する証券規制を巡る論議の動向

市場となっている1)。さらに，米国生保の主力市場となっている個人保険分 野（全収入保険料の61\%）の保険種類別推移を見ると表 1 のとおりとなって いる。これによると，かつて（たとえば，1980年）は，終身保険を代表とす る生命保険が主力（71\%）であったところ，1990年代以降年金に主力の座を 奪われ，その後時々の変動はあるものの，趨勢的に個人年金が最大のウェ一 トを占め現在（2010年の54\%）に至っている。

次に主力の個人年金について一般的区分である変額年金・定額年金別にそ のウェートの変遷を見ると, 表 2 のおりである。かつては定額年金主力 （1985年は83\%）であったが，とりわけ1990年代以降に株式市場の堅調や積 極的な商品開発の影響を受けて変額年金が市場に浸透した結果，2008年のリ ーマンショックによる一時の落ち込みが見られたものの，2010年時点ではな お変額年金が $63 \%$ と個人年金市場の主力を占めている。

表 1 : 個人保険収入保険料推移 （単位：億ドル，カッコ内は占率\%）

\begin{tabular}{|c|c|c|c|c|c|c|}
\hline & 1980 年 & 1990年 & 1995年 & 2000年 & 2005年 & 2010年 \\
\hline 生 保 & $307(71)$ & $606(47)$ & $785(44)$ & $1,025(38)$ & $1,119(35)$ & $795(23)$ \\
\hline 年 金 & $63(14)$ & $537(42)$ & $774(43)$ & $1,397(51)$ & $1,670(53)$ & $1,899(54)$ \\
\hline 医 療 & $64(15)$ & $141(11)$ & $228(13)$ & $300(11)$ & $378(12)$ & $812(23)$ \\
\hline 合 計 & 434 & 1,284 & 1,787 & 2,722 & 3,167 & 3,506 \\
\hline
\end{tabular}

(出典) ACLI, 2010 Life Insurance Fact Book, 2010 等より作成。

表 $2 ：$ 個人年金商品別占率推移

(単位：\%)

\begin{tabular}{|c|c|c|c|c|c|c|}
\hline & 1985年 & 1990年 & 1995年 & 2000年 & 2005年 & 2010年 \\
\hline 変額年金 & 17 & 26 & 51 & 72 & 63 & 63 \\
\hline 定額年金 & 83 & 74 & 49 & 28 & 37 & 37 \\
\hline
\end{tabular}

(出典) LIMRA, U.S. Individual Annuity Yearbook-2010 等より作成。

1) ACLI, Life Insurance Fact Book 2011, 2011. 
一方，定額年金市場について見ると，表 3 のとおりとなっている ${ }^{2)}$ 。一般 的に個人定額年金（据置型）は，代表的な生保リサーチ機関であるリムラ (LIMRA）によると，一般型，市場価額調整型，株価指数連動型に分類され ている。

このうち一般型は伝統的な (据置) 定額年金で，契約者が一時払いまたは 定期払いの保険料を生保会社に払い込み，契約所定の経費控除後の保険料積 立金に対して所定の利率が付与され，将来の年金原資が積み立てられる（積 み立て段階)。将来の所定時期（たとえば，60歳）に到達すると年金原資を 基礎に終身年金等が契約者に対して支給される（支給段階）。中途解約する 場合には，解約価額は保険法令上（不没収価格規制）の下限を下回らないよ うに設定される。したがって，法令上の下限を超過するように解約価額が設 定されているという意味において，元本・利息が保証されている。

\section{次に，市場価額調整型商品 (Market Value Adjusted Annuity, MVA)}

は，解約価額が金融情勢に応じて所定の範囲内において調整される商品であ る。すなわち，一般的に市場金利が最低保証金利に比して高い場合における 解約に対しては，解約控除が高めに設定される傾向にある。

三番目の株価指数連動型年金の内容は後述のとおりであるが，概略すると 払い込み保険料に対して付与すべき利息につき，契約上所定の株価指数等外 部のインデックスに関連させてその額を決めていく商品である。株価指数等 のインデックスにリンクさせるという意味で，投資商品的な性格も有するが, 一方において，保険法令にしたがい契約上最低利率・元本保証があることか ら一般の定額年金に類似した性質をも有している。いわゆる投資商品と定額 商品両者の中間的性質を持ったハイブリッド型商品ということができる ${ }^{3)}$

2）リムラ統計では，据置年金に，即時開始年金（immediate annuity）および 損害賠償金支払い用年金（structured settlements）を加えたものを定額年金 の合計としているが，本稿では後二者を除外している。後二者の定額年金全体 に占めるシェアは，2009年時点で約 $12 \%$ である。

3） 米国の株価指数連動型年金の内容等については，小松原章「米国の株価指数 連動型年金の動向」『ニッセイ基礎研 REPORT』2009年 8 月を参照。 
米国の株価指数連動年金に対する証券規制を巡る論議の動向

定額年金分野の販売実績推移を見ると，従来は一般の定額年金が主流であ ったところ，2000年代に入ると株価指数連動型年金の成長振りが顕著となっ ている。

表 3 : 定額年金 (据置型) の種類別占率推移 （単位：パーセント）

\begin{tabular}{|l|c|c|c|c|c|}
\hline & 2001年 & 2003年 & 2005年 & 2008年 & 2010年 \\
\hline 一般型 (簿価保証型) & 73 & 72 & 54 & 53 & 44 \\
\hline 市場価額調整型 (MVA) & 16 & 10 & 6 & 19 & 9 \\
\hline 株価指数連動型 & 11 & 18 & 40 & 28 & 47 \\
\hline
\end{tabular}

(出典) LIMRA, U.S. Individual Annuity Yearbook-2010 等より作成。

次にこの成長顕著な株価指数連動型年金の取り扱い生保会社, 販売チャネ ルについて同じくリムラ調査により見ると，次のとおりとなる。

株価指数連動型年金の上位 3 社は，2009年実績で，アリアンツ・ライフ， AVIVA（保険料で英国第 4 位)，アメリカン・エクイティ社であり，欧州系 生保中心の新興生保会社となっている。これに対して, 変額年金, 一般の定 額年金の上位 3 社は, 前者が, プルデンシャル, メットライフ, TIAACREFF (米国大学教職員退職年金・保険基金)，後者が，二ューヨーク・ラ イフ, AIG グループ, メットライフとなっており, いわゆる伝統的な大手生 保会社が占めている。

一方，販売チャネルについて見ると，株価指数連動型年金は，独立保険工 ージェントが主流（販売占率 $84 \%$ ）となっている。これに対して，変額年金 は証券系販売人（独立証券ブローカー・ディーラー，大手株式ブローカー等, 48\%)，キャリアー・エージェント（18\%）であり，一般定額年金は，独立 保険エージェント $(35 \%)$, 銀行 $(31 \%)$ となっている。

要するに，株価指数連動型年金は，欧州系の新興生保会社が引受，独立保 険エージェントが販売を行うという意味で，変額年金や一般定額年金とは異 なった市場を形成している。 


\section{2 . 株価指数連動型年金の内容}

前記のとおり株価指数連動型年金は，生保業界では定額年金の一種と位置 づけられている。そこでこの商品の内容について NAIC（全米保険監督官協 会）のバイヤーズ・ガイドに基づいて見ると，株価指数連動型年金（EquityIndexed Annuities）とは，定額年金の一種で，払い込み保険料に対して株 価指数に連動した利息が付与されつつ保険料積立金が累積するとともに，将 来の所定の時期に蓄積した保険料積立金を基礎に年金支給がなされる方式の 商品である4)。利息算定の基礎となる指数（インデックス）は，S＆P 500 な どの株価指数である。株価指数連動型年金はまた，定額指数連動型年金 (Fixed Indexed Annuities, FIA) とも称されている。

株価指数連動型年金は，株価指数という保険会社から独立した外部指標の 変化率に契約所定の調整（具体的には引下げ調整）を行った利息が付与され るため，指数等の変動の影響を被るという意味で，利息の不確定要因を有す ることになるが，次のような保証が契約上付与されていることから，変額年 金のように契約者が投資リスクを負うことは少ないものと考えられてきた ${ }^{5)}$ ・全払い込み保険料のうち所定の部分（諸経費控除後の残額で，払い込み保 険料の $87.5 \%$ か $100 \%$ の間）を元本とし，これが保証される。

・各州の不没収価格法で規定される最低保証利率（1％から3\%の間の利 率）が付与され，これらが元本に繰り入れられる。

・最低保証利率を超過する利息（契約上定められた所定の方式に基づく計算 される）が追加的に付与されると同時に，これらが元本に繰り入れられる。 このようにひとたび超過利息を含めて契約者に付与され元本として組み込 まれると，それらは将来の運用実績にかかわらず，減じられることはなく確

4) NAIC, Buyer's Guide to Equity-Indexed Annuities, 2007.

5) NAFA, White Paper on Fixed Indexed Insurance Products including Fixed Indexed Annuities and Other Fixed Insurance Products, November 10, 2006, pp. 6-7. 
米国の株価指数連動年金に対する証券規制を巡る論議の動向

定した金額となる。

具体的な利息の付与方法は，商品ごとに種々の手法が見られるが，ひとつ の主要な方法について見ると，(i)利息を付与すべき対象期間は通常 1 年間単 位，(ii)この期間に対応する株価指数の変化率を，S＆Ｐ５00やダウジョーンズ 30等の期始と期末の変化率とし，この変化率（上昇率）に一定程度連動させ る，という形で行われる。

\section{3 . 株価指数連動型年金に対して新たな証券規制に動き出した SEC}

1990年代半ば（1995年といわれる）に登場してきた株価指数連動型年金は, 表 3 に見られるとおり，2000年代に入り著しい成長を遂げ，定額年金分野の 中心的存在を占めるに至った。この商品については，生保業界では前記のと おり定額年金の一種と位置づけられているものの，一方で契約者に帰属する 利益（付与利息）が，証券指数の変動にリンクし，収益が変動する証券的な 側面も見られる。しかしながら，その証券法上の位置づけは不明確なまま 2000年代後半に至った。

したがって，この商品は，一般的に証券規制に服さず，新規商品販売の際 の SEC への登録，商品販売（募集）の際の証券ライセンスの取得など証券 諸法上要求される規制が適用されてこなかった。この点が一般の証券同様に 証券規制に服する変額年金等との大きな相違のひとつであった。

一方，この株価指数連動型年金の販売が急速に伸びる中で，不適切な販売 も見られるようになり，証券規制当局の関心を喚起するようになった。そこ で，まず，自主規制機関である当時の NASD（全米証券業協会）が2005年 8 月に会員宛通知を出し，傘下の会員（ブローカー・ディーラー）に対して 系列の販売人（保険募集人）による証券法上未登録の株価指数連動型年金に かかわる監視体制の強化を要請した6)。このような中で，SEC が新たな動き を見せ，2008年 6 月に株価指数連動型年金に証券規制をかける趣旨の新規則

6) NASD, Notice to Members 05-50:Equity-Indexed Annuities, August 2005 . 


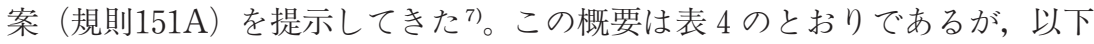
でその経緯・内容を紹介する。

SEC が規則を導入しようとする背景には，株価指数連動型年金販売が急 成長を遂げるのにともない，不適正販売にかかわる苦情（複雑な商品内容の 不適切な開示等）が発生している実態が見られるため，これまで連邦証券法 上未登録であった株価指数連動型年金に対して証券法上の位置づけを明確に するガイダンスが必要であると認識するようになった点が挙げられている。

米国ではこれまでも年金商品の普及にともない商品の多様化（利率保証契 約の出現等）が進み，この過程で証券法適用の有無に関する疑義が生じる事 例が発生したことから，証券法適用の有無を判断するための規則（規則151） が1986年に制定された経緯がある。

規則151の概要は次のとおりで，その趣旨は，本規則（(a)，(b)双方）に合 致した年金契約は証券法の適用をしないとする，いわゆるセーフ・ハーバー 規則である。

(a)保険会社が保険期間にわたって，(i)販売・管理経費その他の経費控除後の 払い込み保険料および付与した利息を保証すること，かつ，(ii)州保険法に規 定する最低利率以上の所定の利息を付与すること。

(b)保険会社が上記の最低保証利率を超える利息を付与する場合には， 1 年に つき 2 回以上，これを変更してはならないこと（すなわち，最低 1 年間保証 すること）。

これらの条件を満たした年金契約は，証券法の適用を免除されることとな るが，SECは，株価指数連動型年金（規則制定時の1986年には存在しなか った商品）については，後者の(b)を満たしていないものと判断している。し たがって，規則151を満たさないと考えられている株価指数連動型年金につ いては，証券法上の取り扱いが不明確なままとなっている。こうした事情に 鑑み，SECは，証券法適用除外とする範囲を確定し，株価指数連動型年金

7) SEC, Release Nos. 33-8933, 34-58022: File No. S7-14-08, June 25, 2008 . 
の契約者に対して証券法上与えられる便益（適切な開示，不適正販売の排除 等)を確保するため，本規則案を提示するに至った。

\section{表 4 ：規則151A；証券法適用除外の年金契約に該当しない年金契約（抜粋）}

\begin{tabular}{|c|c|c|}
\hline 項目 & 提案時の内容（2008年 6 月） & 採択時の内容（2008年12月） \\
\hline $\begin{array}{l}\text { (a)一般 } \\
\text { 規定 }\end{array}$ & $\begin{array}{l}\text { 保険会社が発行した年金契約であっ } \\
\text { て，か，年金契約として保険法の規 } \\
\text { 制に服するものである場合，以下 (の } \\
\text { 双方) に該当するものは, 証券法適用 } \\
\text { 除外の年金契約ではない。 } \\
\text { (1)保険会社が契約上支払う金額が，全 } \\
\text { 部もしくは一部にかかわらず，証券の } \\
\text { グループもしくはインデックスを含め, } \\
\text { 証券の運用実績に関連させて計算され } \\
\text { る契約。 } \\
\\
\text { (2)保険会社が契約上支払う金額が, 契 } \\
\text { 約上保証された金額を上回る可能性が } \\
\text { 高い（more likely than not to } \\
\text { exceed）契約。 }\end{array}$ & $\begin{array}{l}\text { 保険会社が発行した年金契約であっ } \\
\text { て, かつ, 年金契約として保険法の規 } \\
\text { 制に服するものである場合, 以下 (の } \\
\text { 双方)に該当するものは, 証券法適用 } \\
\text { 除外の年金契約ではない。 } \\
\text { (1) } 1 \text { 以上の所定の利率付与期間末 (あ } \\
\text { るは後) に保険会社が契約上支払う } \\
\text { 金額が, 全部もしくは一部にかかわら } \\
\text { ず, 証券のグループもしくはイデッ } \\
\text { クスを含め, その利率付与期間中の証 } \\
\text { 券の運用実績に関連させて計算される } \\
\text { 契約。 } \\
\text { (2)保険会社が契約上支払う金額が, 契 } \\
\text { 約上保証された金額を上回る可能性が } \\
\text { 高い (more likely than not to } \\
\text { exceed) 契約。 }\end{array}$ \\
\hline $\begin{array}{l}\text { (b)契約 } \\
\text { 上支払 } \\
\text { う金額 } \\
\text { 执よび } \\
\text { 契約上 } \\
\text { 保証さ } \\
\text { れた金 } \\
\text { 額の決 } \\
\text { 定 }\end{array}$ & 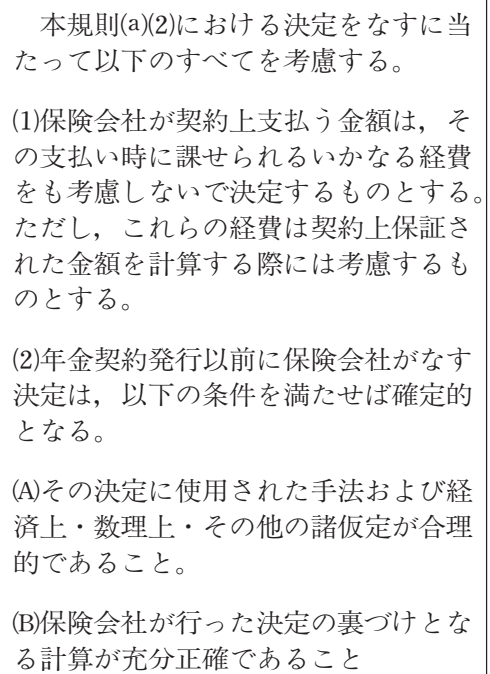 & $\begin{array}{l}\text { 本規則(a)(2)に损ける決定をなすに当 } \\
\text { たって以下のすべてを考慮する。 } \\
\text { (1)保険会社が契約上支払う金額および } \\
\text { 契約上の保証金額は, 支払い時に課せ } \\
\text { られる経費 (上限なし) を含めたすべ } \\
\text { ての経費を考慮して決定するものとす } \\
\text { る。 } \\
\text { (2)年金契約発行以前に保険会社がなす } \\
\text { 決定は, 以下の条件を満たせば確定的 } \\
\text { となる。 } \\
\text { (i)その決定に使用された手法および経 } \\
\text { 済上・数理上・その他の諸仮定が合理 } \\
\text { 的であること。 } \\
\text { (ii)保険会社が行った決定の裏づけとな } \\
\text { る計算が充分正確であること }\end{array}$ \\
\hline
\end{tabular}


この規則案（規則151A）の大意は，「本規則に合致した年金契約は，証券 法適用除外の年金契約ではない」とし，株価指数連動型年金に対して証券法 を適用するというものである。より具体的に見ると，(i)保険会社による支払 額が証券インデックスに関連して定まる契約，かつ，(ii)その支払額が最低保 証額を上回る可能性が高い契約である場合には，証券法を適用するというも のである。したがって，まさしく株価指数連動型年金に対して証券法を適用 するという内容である。

規則案では，契約上の支払額が最低保証額を上回る可能性が高いかどうか の決定条件〔(b)(1)抢よび(b)(2)〕が提示されているが，これらの具体的適用は 数理技術を有する生保会社が，プリンシプル・ベースの手法により行うもの としている。

大方の株価指数連動型年金は本規則に合致する可能性が高く，証券法の適 用を受けるものと考えられることから，この商品で成長してきた生保会社に とっては，コンプライアンス・コストの負担増などによる負担感が増すもの と考えられる。

\section{3 . 規則151A 導入提案に対する生保業界の反応}

SEC では規則案を公表した際（2008年 6 月 25 日），当初 9 月 10 日を期日と するパブリックコメントを募集した。しかし，この期間では短すぎて充分な 検討ができないとする意見が強かったこともあり，その後期日を 11 月 17 日ま で延長した ${ }^{8)}$ 。

SEC の提案に対しては，業界全体で反対というわけではなく，生保各社の 意見は大きく分かれたのが特徵的である。すなわち，前記のとおり，株価指 数連動型年金は，欧州系生保会社等の主力商品でもあることから，これらの 会社が規則導入に強く反対したのに対して，メットライフやニューヨーク・ ライフなどの伝統的大手生保会社グループは，導入に賛成ないしは条件付賛

8) SEC, Release Nos. 33-8976, 34-58769: File No. S7-12-08, October 10, 2008 . 
米国の株価指数連動年金に対する証券規制を巡る論議の動向

成という形で柔軟な姿勢を示した。

導入反対会社の代表格は，株価指数連動型年金上位 2 社のアリアンツ, AVIVA であった。アリアンツ社の反論の概要は，株価指数連動型年金は， 州保険法の不没収価格法上の要件を満たし，元本，付与利息が保証されてい るから保険であるというものであった9)。AVIVAもアリアンツ社同様に， 株価指数連動型年金は，保険であり証券ではないとして規則導入に強く反対 した ${ }^{10)}$ 。AVIVAによれば，本規則が要求するテストは，証券法上の適用除 外を決定するための要件を大きく変更するものであり，判例や SEC の従前 の解勫によって支持されないとした。したがって，このような規則が導入さ れることになれば，証券の概念を変質させるだけでなく，その他の年金商品 に対する訴訟リスクを高めることにもなると述べた。

これに対してメットライフ等大手生保会社は，SECの提案に好意的な対 応を見せた。たとえば，メットライフは，株価指数連動型年金に対する証券 規制の適用は，この商品に関する適合性等の販売問題を明確にするとともに， 株価指数連動型年金と変額年金との間の公正取引条件の確保にも資するとし $た^{11)}$ 。

また，ニューヨーク・ライフも株価指数連動型年金は証券であり，証券規 制を適用することにより，投資者に対する完全な開示や販売上の保護が与え られることになり，州保険法上の規制と併せて投資者保護が実現できると積 極的な評価を下した ${ }^{12)}$ 。

SECの規則提案に対して生保業界代表としての ACLI（米国生保協会）は，

9) Allianz, Re:Proposed Rulemaking Regarding Fixed Indexed Annuities ; File No. S7-14-08, September 10, 2008.

10) AVIVA, Re:File Number S7-14-08; Indexed Annuities and Certain Other Insurance Contracts, September 10, 2008.

11) MetLife, Re:File No.S7-14-08 (Indexed Annuities and Certain Other Insurance Contracts), September 11, 2008.

12) New York Life, Re:Comments to Proposed Rule Regarding Indexed and Certain Other Insurance Contracts (File No.S7-14-08), September 18, 2008. 
業界内の複雑な事情を反映してか，規則の実務管理上の困難性，訴訟リスク の恐れ，証券法，SECの監督経緯等についての検討の必要性を列挙してい る程度で業界としての明快なコメントをなしえていない情勢にあった ${ }^{13)} 。$

これに対して定額年金の業界団体またはその関連団体として SECの提案 に対して積極的な反論を行ったのは，NAFA（National Association for Fixed Annuities，米国定額年金協会）であった ${ }^{14)}$ 。NAFA は，提案規則 （規則151A）は無効であると強く訴えているが，その主な根拠は以下で紹介 するとおり，概ね(a)株価指数連動型年金はそもそも，法令，最高裁判例に照 らして証券ではない，(b) SEC は州の保険規制を理解していない，(c) SEC は 規則導入に必要な効率性等の分析を行っていない，とするものであった ${ }^{15)}$ 。

\section{(a)株価指数連動型年金は証券法, 最高裁判例に照らして証券ではない}

最高裁判例を基礎としたSECの伝統的考え方は，年金契約が以下の項目を保証し ている場合には，保険会社が必要とされる相当の投資リスク (substantial investment risk）を負担していると見なして証券法適用除外としてきた ${ }^{16)}$ 。

・契約者の払い込み保険料額（ただし，諸経費控除後），すなわち当初の元本部分

·保険期間中に付与される最低保証利率

・付与済みの最低保証利率および超過利率，すなわち利息として確定し，元本に加え られた部分

13) ACLI, Re:Preliminary Comments on Proposed Rule 151a and Proposed Rule 12h-7, September 19, 2008.

14） NAFA は主として定額年金に関する教育・啓蒙活動を行う非営利の団体で あり，会員は，保険会社，保険募集人，ブローカー，コンサルタント，消費者 で構成されている。独立の啓蒙団体となっているが，実質的には，株価指数連 動型年金を含む生保業界の意見を主張する機能も有しており，今回の SEC 提 案にも積極的な反論を行っている。

15) NAFA, Re:Comments on Commission's Securities Act Release No. 8933 and Securities Exchange Act Release No. 58022 (June 25, 2008), September 10, 2008, pp. 10-37.

16) 反論等で参照される主要判例は, (a) SEC v.VALIC, 359 U.S. 65 (1959) お よび(b) SEC v. United Benefit Life Ins. Co., 387 U.S. 202 (1967) である。 
米国の株価指数連動年金に対する証券規制を巡る論議の動向

株価指数連動型年金はこれらの要件を満たすが，SEC は，保険会社の支払額が保 証額を超過する可能性が高いかどうかという新たな異質の基準を提案してきた。この 基準は最高裁判決からかけ離れた整合性のないものである。また, SEC は証券法適 用除外とするためのセーフ・ハーバー規則である規則151を採択（1986年）し，この中 で, 保険会社が元本, 最低保証利率抒よび付与済み利率を保証している場合には, 年 金契約にこの規則を適用し，証券法適用除外とすると定めてきた。これは，保険会社 が元本保証, 最低利率および付与済み利率を保証することにより, 相当のリスクを負 担しているとの想定である。

ところが，SECの提案では，株価指数連動型年金はリスクを減じると認めつつも， 一方で契約者の投資リスクを排除していないと論じている。これは SECが規則151を 採択し，株価指数連動型年金が規則151に該当するとの原則を立てたことと矛盾する。

(b) SEC は州の保険規制を理解していない

SEC の提案は，株価指数連動型年金の監督レベル向上に対する州の継続的な努力 および当該年金の元受保険会社および保険募集人に対する規制等州保険法による当該 年金に対する規制内容（特質・程度）を理解していない。州規制から見ると，(i)新規 則（151A）がもたらす便益は，すでに州の規制によって満たされているので，この 規則は不要である，(ii)当該年金は，州規制に服する保険会社によって発行され，契約 者は証券として見なされる要素である損失リスク（元本損失）を負担していない。

(c) SEC は規則導入に必要な効率性等の分析を行っていない

SECによる今回の提案は, 規則制定に必要とされる次の要件を満たしておらず, 欠陷がある。

(i)効率性向上に資するかどうかについての厳格な分析がなされていない。規則 $151 \mathrm{~A}$ は，定額年金に対する効率的な販売規制を行う州規制によらずして，連邦証券法上の 登録義務を通じて特定の販売行為を是正しょうとする点で，効率性向上に貢献しない。 (ii)規則151A が競争促進に貢献できるかどうかについての厳格な分析が示されていな い。証券法上の登録義務が競争促進に与ええる効果や当該年金と類似商品（ミューチ ユアル・ファンド等) 間の競争促進効果が不明である。

(iii)規則151A による資本形成効果に関する厳格な分析が明らかにされていない。すな わち，株価指数連動型年金に対する販売抑止効果を有する規制上のコスト負担が，資 本形成に貢献するかどうかが明らかにされていない。

\section{4. 規則採択に踏み切った SEC}

生保業界の賛否両論のなかで，SEC は2008年12月に規則151A を採択し， 


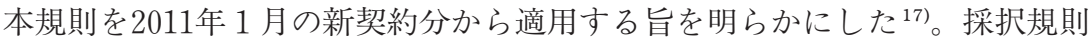
の内容は表 4 のとおりであり，概ね提案時の内容を受け継いでいる。したが って，株価指数連動型年金は，規則上の定義に当てはまり，当該商品に対し て証券法が適用される可能性が非常に高くなった。

業界反論（NAFA 等）にも見られるように，従来の発想では契約者の投 資リスク負担の程度（投資リスクの引受）が証券性の重要な決定要因であり, この場合の投資リスクは主として投資資産の価格変動による元本割れリスク が想定されていた。しかしながら，SEC 規則では，プラスの範囲の収益率 であってもこれらが変動することによる不確実な状態自体がリスクであると いう発想が採用されており，この意味で従来の発想から踏み出したともいえ る主張がなされた。

さらに，SEC は規則151の「超過利率は最低 1 年間保証されなければなら ない」点について，超過利率保証は将来に向かって 1 年間保証されなければ ならないという解釈をしており，株価指数連動型年金のように 1 年経過して 事後的に超過利率が定まるケースは該当しないとの立場を取った。この結果, 規則151を根拠とする証券法適用除外を主張することはできないとした。し たがって，生保会社が自社の商品について証券法の適用除外を主張するには， 規則の趣旨を勘案したプリンシプル・ベースのシナリオ分析（数理的・経済 分析）を行うことにより，自社の商品が規則の定義に合致しないこと（証券 法適用除外）を立証していかなければならない。

また，SECは業界反論で指摘された規則導入による効率性，競争促進性， 資本形成への影響については次のように分析した ${ }^{18)}$ 。

\section{(i)効率性を高める}

規則151A は，株価指数連動型年金に対する連邦証券法適用により，ディスクロージ

17) SEC, Release Nos. 33-8996, 34-59221; File No. 7-14-08, January 8, 2009 .

18) SEC, op. cit., pp.130-141. 
米国の株価指数連動年金に対する証券規制を巡る論議の動向

ヤーおよび販売規制から得られる消費者保護利益が拡大することから, 効率性が高ま る。ディスクロージャーにより種々の商品情報, すなわち, 解約控除, 収益率算定法, 最低保証等が明らかにされるから，投資者は投資決定能力が向上し，ひいては証券市 場における効率的な資本配分がもたらされる。また，消費者は適合性原則に合致した 助言を受けられる点を含めて，販売規制にともなう投資者保護上の便益を享受するこ とができる。これにより，投資決定能力の向上を通じて証券市場の効率性が高められ る。

\section{(ii)競争を促進する}

規則導入により透明性が高まるので, 従来証券法上の地位が不明確であったため株価 指数連動型年金への参入を躊躇していた保険会社が市場参入しやすくなるから競争促 進が見込まれる。同様に現在証券未登録の当該商品の販売に消極的であったブローカ 一・ディーラーは，本規則により証券法上の地位が明確にされたことにより，登録商 品としての販売意欲が生じることになるから，株価指数連動型年金の販売業者間の競 争が促進される。

\section{(iii)資本形成（capital formation）を促進する}

本規則の導入による投資者保護を通じて実現した市場効率性の向上効果が保険会社, 販売業者および投資者間の情報の量質を改善することにより資本形成が促進される。

このように規則151A は SECにより採択されることにはなったが，同時 にコミッショナー 5 名のうち 1 名（Troy A. Paredes）が規則採択に反対 するという事態が生じた。このコミッショナーの主な主張は，(i)規則 $151 \mathrm{~A}$ は，証券法適用除外の年金（株価指数連動型年金）について適用除外をはず し，SECの規制対象に加えようとしているが，これはSECの権限を超えて いる，(ii)証券法上の投資リスクとして最低保証額の超過可能性を扱うのは不 適切で，下方リスクの程度（損失リスクの程度）を強調するのが適切である， (iii)規則151A は，投資リスク一点に焦点が当てられているが，もう一方の重 要要素である「年金の販売方法」に適切な配慮がなされていない，等とする ものである ${ }^{19)}$ 。そして，この規則はすべての株価指数連動型年金に対して証

19) SEC, Speech by SEC Commissioner: Openings Remarks and Dissent Regarding Final Rule 151 A, Indexed Annuities and Certain Other Insurance Contracts by Commissioner Troy A. Paredes, December 17, 2008 . 
券法適用対象とする可能性が高いとし，規則の目的が問われるとも批判して いる。

\section{5 . 規則151A の撤回を求めて提訴に動き出した関係生保業界}

この SECによる規則採択を受けて，株価指数連動型年金を主力とするア メリカン・エクイティ社等の生保業界 6 社は，2009年 1 月に規則 $151 \mathrm{~A}$ の撤 回を求めて連邦控訴裁判所（コロンビア特別区）宛訴訟を提起した ${ }^{20)}$ 。同様 に州の主張を代弁する NAIC（全米保険監督官協会）も SEC に異議申立て を行い，同年 2 月に提訴に踏み切ることになり，同月に裁判所の命令により 訴訟の併合が行われた。審理に先立ち, アメリカン・エクイティ社等 6 社は, 同年 2 月にその主張をまとめた意見書（Brief）を裁判所宛に提出した。こ れによると原告団の主張は概ね次のとおりである ${ }^{21)} 。$

\section{(a)株価指数連動型年金は証券法適用除外の年金である}

SEC は規則採択時のリリースで，株価指数連動型年金はミューチュアル・ファン ド，変額年金等と多くの点で類似して抢り，その購入者はこれらの投資者と同じく相 当のリスクを負担している，と指摘している。しかし，これは最高裁判例（バリック， ユナイテッド・ベネフィット事件）で検討された 2 つの理由により誤りである。第一 に, 株価指数連動型年金は保険会社の一般勘定において投資され，契約価額は保険会 社の投資管理に基づかない。第二に，投資リスクとは，基本的に投資元本の損失にか かわるリスク，すなわち，購入者の投資資金が証券価格の下落によって喪失するか減 少するかという意味でミューチュアル・ファンドや変額年金の購入者が負担するリス クのことである。

変額年金契約者の資金は分離勘定で保持され，契約者には全投資成果が反映される から, 理論上勘定残高はゼロになりうる。これに対して株価指数連動型年金は，所定

20）他の 5 社は, BHCマーケティング社, ミッドランド・ナショナル・ライフ, ナショナル・ウェスタン・ライフ, OM フィナンシャル・ライフおよびタッカ ー・アドバイザリー・グループである。

21) Final Brief: Oral Argument Scheduled for Friday, May 8, 2009, No. 09-1021 in the U.S. Court of Appeals for the District of Columbia Circuit, February 17, 2009. 
米国の株価指数連動年金に対する証券規制を巡る論議の動向

の元本返還が保証され，契約価額には所定の利率付与（年率 $1 \%$ から $3 \%$ ）がなされ るなど，元本損失リスクが排除されている。これらの保証要素は伝統的定額年金と同 一である。

(b)規則151A は証券法, 最高裁判例等に照らして恣意的・気まぐれであり矛盾している

SEC は，ある年金契約が証券法適用対象になる場合があるとし，特定の株価指数 連動型年金がこれに該当すると結論付けている。規則自体で用語を定義したjえで， 年金として州保険法に服する商品を証券として選定している。いかなる年金を証券と して規制すべきかについて定める権限は，SECにはない。証券法は一般的に年金契 約をSECの規制から除外している。

また，SECの規則151A は，証券性を判断するための購入者にとっての投資リスク が, 投資元本の喪失可能性であるとした最高裁判決と矛盾している。購入者が保証金 額あるいはそれを上回る金額を回収する可能性が高いという状況はまったくリスクに 当たらない。SEC は期待収益率からの乘離が金融商品において広く認められている リスクの定義であるとしているが，このような取り扱いは誤りである。

そのほか, 証券性を判断する際に行われる重要なマーケティング・テスト（商品が 業者により投資的要素をべースに販売されているかどうか）が行われていないことや 株価指数連動型年金がセーフ・ハーバー規則151に合致している点（利率付与方式が毎 年決定され，利息が毎年付与されるから規則に合致している）が配慮されていないこ とが問題である。

(c)規則導入に必要な効率性・競争促進性・資本形成促進に関する検討がなされていな い。

証券法上の規則制定に際して SEC は, 当該規則が効率性, 競争状況および資本形 成に与える効果を検討しなければならない。規則導入コストが適切に考慮されていな い規則は無効とされる。

SEC はパブリック・コメントにおいてあるコメンテーターが試算した保険募集機関 およびそのエージェントの収入減少 15 億ドルおよび保険会社の収入減少 3 億ドルにつ いて論じていない。SEC はこのような高コストも正当化できるとしているが, SEC が解釈による裁量を行使する限り，高コストな規則が必要かどうか，そして，州がこ れまで適切な対応をしているのかどうかの検討を拒否することは, 効率性, 競争状況 および資本形成に与える分析義務を放棄したことにほかならない。

\section{6 . 連邦控訴裁判決の内容一規則導入に必要な効率性等の分析が 不十分とした判決}

生保業界の提訴の動きに対応し，SECも規則導入擁護のための意見書を 142 
保険学雑誌 第 615 号

裁判所に提出するなど徹底抗戦の構えで臨み，2009年 5 月から本格審理が始 まった。2009年の夏場までに決着を図りたいとする原告 6 社側の意向の中で, 連邦控訴裁は 7 月 21 日に判決を下した。その概要は次のとおりで，株価指数 連動型年金に証券規制を課すとする規則は妥当であるが，規則導入に必要な 効率性等の分析が不十分であるとし，不備部分補充のための再検討を命じ た ${ }^{22)}$ 。

\section{(a)規則151A は法律上の合理的解釈である}

原告の見解によると，投資リスクは証券の購入者が元本損失の可能性に直面してい る場合のみ存在しているといい，SECが規則151A で行った投資リスクの定義を支持 できないと論じている。しかしこれはディフェンシブ (defensive) な主張である。

株価指数連動型年金は，払い込み保険料に対して最低保証額を付するという点で年 金契約に類似しているが，当該年金の収益率は，一定期間の証券指数の変動に基づい て決められるので，一定期間末まで知ることができないから，明らかに証券により類 似したものとなっている。

これに対して規則151における証券法適用除外となる年金契約には，事前に収益率 が保証されているので，この収益率変動性が除去されている。これらの特徵が示すよ うに，株価指数連動型年金には，伝統的な保険契約には見られない投資要素が伴って いる。したがって，株価指数連動型年金は証券法適用除外となる年金契約には該当し ないとする SECの解勫は合理的である。

\section{(b) SEC による効率性向上, 競争促進および資本形成効果分析は不十分}

行政手続法は，裁判所に対して恣意的きまぐれな，裁量権乱用的な，または，法律 に従わない行政機関の行為を破妄するよう求めている。連邦控訴裁は, 規則 $151 \mathrm{~A}$ が 効率性, 競争促進抢よび資本形成に与える効果に関する SECの検討（分析）は恣意 的できまぐれであるという原告の主張を支持する。

たとえば効率性分析において，SEC は，証券法上のディスクロージャーによる購 入者の投資決定能力の向上拈よび適合的な販売実務により，結果的に大きな効率性が 実現できると説明している。しかしながら，SECの分析は既存の規制（州規制）の もとで，投資者が賢明な投資決定を行い，販売業者が適合的な販売を行える十分な保 護策が存在しているかどうかについて判断できていないので，不完全なものである。 このような不完全な分析は，効率性が向上するというSECの判断を恣意的きまぐれ

22) American Equity Investment Life Insurance Company, et al., v. SEC: On Petition for Review of an Order of SEC, July 21, 2009. 
米国の株価指数連動年金に対する証券規制を巡る論議の動向

なものとしている。

このような不完全さは，既存の州法規制のもとでの競争条件についての事実認定が なされていない競争状況分析および不完全な効率性分析に基づいた資本形成分析にお いても見られる。

したがって，裁判所は，SECによる効率性等の分析は不備であると判断 したため，SECに対して分析の不備に対処するよう規則の再検討を求めた。

\section{7 . 金融規制改革のなかでの最終決着一株価指数連動型年金は州規制 に専属}

控訴裁判決の特徵は，株価指数連動型年金を証券として扱うとする規則の 内容については，SECの考え方どおり合理的であると認めつつ，一方で規 則を実施するための要件である効率性，競争性および資本形成促進について は, SEC の分析が不十分であるとし，分析の十分性を確保するために規則 の再検討が求められた点である。したがって，SECが効率性等について説 得力ある分析を提示することができれば，規則 $151 \mathrm{~A}$ が実効性ある規則とし て成立する余地が残されたという位置づけである。

当判決に対して SEC スポークスマンは，判決で指摘された手続き上の問 題点を引き続き検討したいと述べるなど，未充足の条件を整備して規則導入 に繋げたいとの意向を明らかにした ${ }^{23)}$ 。これに対して原告のアメリカン・エ クイティ社は，SEC 規則の再検討が求められた点を評価する一方で，SEC が指摘された欠陥部分を補強し，規則を再提出する可能性を警戒し，その際 には規則撤回を求めて再反論するとの意向を示した ${ }^{24)}$ 。また規則導入に積極 的な反論を行ってきた NAFA は，(i)この判決は, SEC が将来必要と判断し た場合には，規則を制定できる余地を残したもので，落胆している，(ii)株価

23) Reuters, Update 2-US Court Orders SEC to Reconsider Annuity Rule, July 21, 2009.

24) Karen Mracek, Court Rules against SEC Regulations of Annuities, DesMoinesRegister.com, July 21, 2009. 
指数連動型年金を証券規制によらず，州規制の枠にとどめるよう連邦議会に 働きかけていきたいとの声明を行った。

このような業界情勢の中で，株価指数連動型年金の取り扱いについては連 邦議会でも関心を呼ぶようになり，連邦控訴裁判決直前の2009年 6 月に株価 指数連動型年金を証券法適用除外とし州保険規制に専管させる旨の法案が上 下両院で提出されることとなった（S.1389および H.R. 2733） ${ }^{25) 。 ~}$

連邦議会では一方で，2008年 9 月に発生した金融危機後の金融規制の枠組 みを定めるために，包括的な金融規制改革法案の本格的審議が2009年秋口か ら両院で行われる状況にあった。金融規制改革法案は，2009年12月に下院， 2010年 5 月に上院をそれぞれ通過した後，両院の調整法案が2010年 6 月末か ら 7 月中旬にかけて可決されたのを受け，同年 7 月21日に大統領署名により 「ドッド・フランク法」(Dodd-Frank Wall Street Reform and Consumer Protection Act of 2010) として成立した ${ }^{26)}$ 。

ところが，ドッド・フランク法の最終審議の過程で株価指数連動型年金を 証券法の適用除外とする条項が盛り込まれ，最終的に連邦規制が排除され州 の専管的な規制に服することとされ，規則 $151 \mathrm{~A}$ 導入前の状況が確保される こととなった。ドッド・フランク法 $(989 \mathrm{~J}$ 条) によると, 次のすべての条 件を満たす保険契約または年金契約は，証券法適用除外とされる。（i)契約価 額が分離勘定の運用実績に影響されない，(ii)州の不没収価格法上の要件を満 たす，(iii)2013年 6 月 16 日以降の新契約については，2010年 3 月採択の NAIC （全米保険監督官協会）の年金取引に関する適合性モデル規則（Suitability in Annuity Transactions Model Regulation) 以上の要件を課している規 制を州が採択していること。

25）双方とも “Fixed Indexed Annuities and Insurance Products Classification Act of 2009” と称し，規則151A を無効とし，株価指数連動型年金を証 券法適用除外とする趣旨の法案である。

26）ドッド・フランク法の内容については，杉山欽哉「ドッド・フランク法の概 要と米国保険業界への影響」『生命保険経営』第79巻第 3 号，2011年，pp.90112 を参照。 
米国の株価指数連動年金に対する証券規制を巡る論議の動向

このように，ドッド・フランク法に証券法適用除外条項を盛り込むことに よって SECの規制（規則151A）を排除するという強引な方法で最終決着が 図られた。しかしながら，NAICの年金取引適合性原則（2010年版）は，変 額年金に対する証券規制としての適合性原則と内容面で実質的に同一化を実 現したものであることから，改正前のモデル規則よりも厳格な規制となって いること，また，SECの介入を立法的に排除したこともあり，州の監督責 任は一段と重くなったと考えることができる。

さらに，ドッド・フランク法により，州の保険業に対する一般的監督権限 は留保されたものの，一方で連邦レベルの新たな保険専管組織である連邦保 険局（Federal Insurance Office，FIO）が設置され，保険規制を含む保険

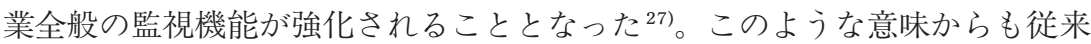
以上に州の監督手法の巧拙が問われる情勢になったと見ることができ，株価 指数連動型年金販売の適切な監督を含州の対応に期待される点は少なくな いものと考えられる。

(筆者は(倮ニッセイ基礎研究所勤務)

27）連邦保険局の機能には，そのほか，(i)システミック・リスクの可能性ある保 険会社の指定，(ii)国際保険問題に関する連邦政策の策定，(iii)国際協定違反の州 法の無効決定等がある。 